\title{
Contribution to the Theory of the Business Success of Transport Organizations
}

\author{
Nena TOMOVIĆ, Milos ARSIĆ, Radoljub TOMIĆ, Ištvan BODOLO, Desanka VLAČIĆ
}

\begin{abstract}
The intensive development of the transport market, the complex demands of transport service users, the growing pressure of competition, the change in values and technical and technological advances forced transport organizations to apply new ways of solving problems related to the survival and business success. Sustainable management of a transport organization is a complex management challenge, first of all in the field of defining key performance and indicators, based on which it is possible to monitor and measure business results. In this respect, the work with an appropriate selection of key performance and indicators has created a framework for the integration of economic, social requirements, requirements for environmental sustainability and performance management. In this way, a set of indicators was developed, which are a measurable category and enable continuous monitoring, business performance of the organization. Bearing in mind certain specificities that are manifested in the business of organizations, both in Serbia and throughout the region, the key contribution of the work can be the research of critical success factors that can be important for the successful operation of transport organizations
\end{abstract}

Keywords: business success; critical success factors; indicators; key performance; transport organization

\section{INTRODUCTION}

Transport organizations are production and technological systems. They deal with the organization and provision of transport services with the aim of achieving certain volume and quality of transport services according to obtained maximum profit (public transport) or minimum costs per unit of service (transport for own needs) which are the basic business frames. The business success of the organization is based on economic principles [11], while some other principles of sustainable development of the organization (sociological, ecological, technicalexploitation and institutional) should be also included.

Economic success is an assumption and a condition for achieving the goals of all participants in the business, on the level of the one company and every transport organizations, and the prerequisite for achieving economic success is the optimal management of the flows of reproduction based on the principle: to achieve maximum results with minimal investments and costs. When the basic economic principle of reproduction is applied to all production factors [15], then optimal economic efficiency is achieved.

The quantification of the success of the organization identified the level of success in realizing the previously set business goals by strategic managers both at the organizational level and at the level of its organizational units, functions, processes and activities, and especially on the level of responsibility of the holders of individual work tasks [16].

The path to success in conditions of liberalized trade with increasing influence of multinational corporations in some parts of the world, which overflow into less developed regions, is not easy. The conditions in which modern organizations work are increasingly complex and uncertain, and the environment is more diversified and more dynamic. The demands placed on organizations are increasingly complex and numerous. They are required to be innovative, to respond quickly and in a timely manner, to be flexible and profitable and to consistently meet very different user needs.

All of the above aspects of the organization are interconnected and can be integrated only with support and engagement of all employees [22]. More and more important is the creativity that individuals carry in themselves and which can only be expressed if the appropriate organization climate existed (with appropriated system of motivation and stimulation). The role of the management of the organization is to recognize the creative individual and to ensure the working conditions in which his ability will be expressed, which in the long run represents a contribution to the better performance of the organization's business.

Strengthening of competitiveness of the organization position is developing with the increase of knowledge of the employees. Management knowledge is especially important because the management transfers this kind of specific knowledge to all employees. Managing the organization's success is based on teamwork, and good learning creates and strengthens team spirit [1].

In addition to the above elements for the successful operation of the transport organization, continuous investment in technologies (with improving processes) and equipment is required, and the application of modern management methods also ensures continuous improvement of the competitiveness on the market where the organization operates.

Today, there are a large number of studies, projects and models of performance management of transport organizations, because so many authors around the globe are concerned with this topic. Scientists and experts in the field of transport have developed a number of guidelines for the selection of performance indicators in this area: the business of transport organizations CalTrans 2008, TRB 2008, strategic planning for CTE 2008, sustainable transport planning CST 2003, STI 2008.

Indisputable is that all organizations in Serbia want to be successful, but the facts that the applied level of application of scientific knowledge is going selectively and insufficiently in practice cannot be avoided, which is the main reason for writing this work that deals with topics related to performance of criteria of the transport organization. 


\section{ESTABLISHING THE CRITERIA FOR THE SUCCESS OF TRANSPORT ORGANIZATIONS}

The latest trends in performance management led to the results orientation, which implied not only the management of effective behavior, but also the achievement of high level of results. This principle implied that every employee is responsible for achieving results in order to contribute to organizational performance. Defined results are primarily related to goals and defined values of key performance indicators.

The process of performance management involves managing the company's performance and strategic development through employee behavior management in accordance with assigned employee objectives which they need to achieve. The process contains both quantitative and qualitative performance measures. The basis for creating the basic elements of the system is the mission and vision of the company for which the values and strategic goals are set as key components for defining the behavior standards (required competencies) and goals, i.e. indicators of the key performance that are managed in the direction of organizational vision [9]. In traffic and transport theory and practice, the organization's business success is treated differently, especially when assessing the state of the organization, its subsystems, processes, and the results achieved. The differences arise depending on:

- The aspect of interest and importance of observation and its objectives,

- The development policy, goals and strategies in the country and the environment,

- The degree of comprehensiveness of technologies,

- The measurement and monitoring of objects,

- The targeted using of the "Key Performance Indicators Service" (KPIs) by decision levels (strategic, tactical, operational), as well as access to management of the organization [10].

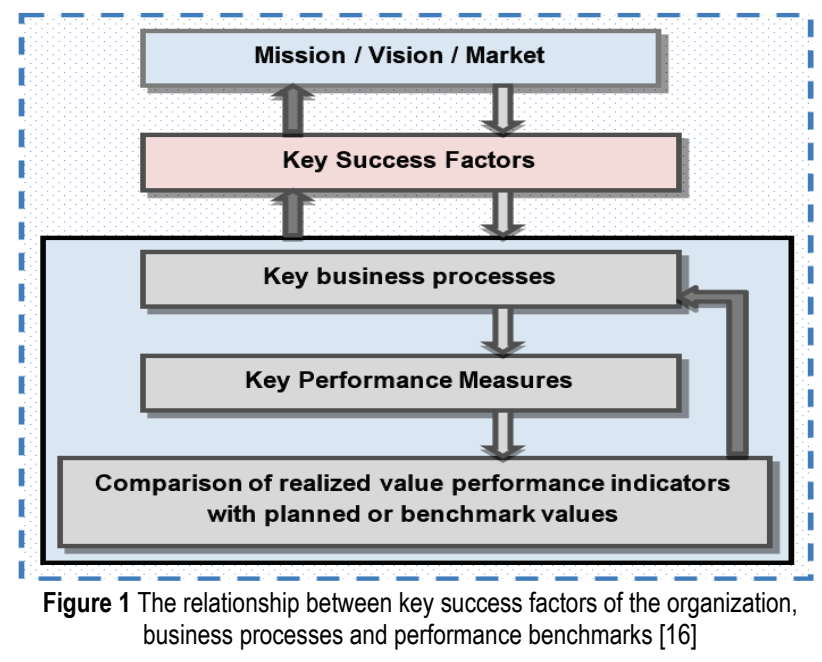

The key success factors of the transport organization are mainly based on the defined strategy and are the basis for identifying key processes and key criteria performance, and derive from the mission and vision of an organization and a strategic assessment of the transport services market [16]. Fig. 1 shows the relationship between key organizational success factors, business processes, and performance metrics.
The illustration shows that the key factors of success cannot be directly managed, which is why it is necessary to connect at the second level with key business processes, which in the third step lead to key performance and process performance measures of all the organization's resources. The key factors for the success of transport organizations are complex, which is why it is necessary to explain in more detail the meaning of the process approach to managing the performance of the organization, based on key business processes and key performance criteria in order to create the path of conditions for measuring of the performance.

\section{KEY PERFORMANCE AND INDICATORS IN RELATION TO SUSTAINABILITY REQUIREMENTS}

Principles of sustainable development provided new elements related to reviewing of reliable indicators important for transport system. Some of them are specialized in large scale while others cover a wide scope of work. It is clear that there are no standardized units of indicators which can provide overall and sustainable planning of transport. Each social environment or institution must develop its own unit of indicators aligning with its needs and possibilities [14]. Indicators related to sustainability of transport system (organization) are used for quantification of multidimensional effect of transport on environment-they represent "strategy management tool" for operationalization of concept of sustainable transport, which provided them important role in the policy of transport.

Procedure of selection of indicators should be conducted according to international criteria of sustainability while respecting overall rules of selection such as the following:

- Scientific basis,

- Relevance according to needs of potential users,

- Measurability,

- Possibility of representing a wide scope of system condition,

- Sensibility to changes,

- Development according to exact and available data,

- Development according to available data,

- Understanding of interpretation,

- Comparability, rentability of data collection,

- Attraction to media, punctuality and so on. [17, 19].

Defining of units of indicators for estimation of transport sustainability represented certain challenge for many authors and institutions.

Study developed by ECJRC-a (European Commission Joint Research Center) suggested application of synthesized unit of 55 indicators, which should provide the estimation of transport sustainability through the following five dimensions:

Economic dimension-the basis of this dimension includes providing economic prosperity for current and future generations since the traffic represents support for economic activities.

Sociological dimension-it is related to equally providing "traffic benefits" to various social groups and generations. 
Ecological dimension-it includes the use of renewable resources to the level of their regeneration and the use of non-renewable resources to the level of their possibility for development of renewable substitutes.

Technical-exploitation dimension-it is related to topics such as occupancy of the vehicle and load factor, since this contributes to sustainable use of resources and their performances.

Institutional dimension-it is related to measures for promotion of transport sustainability.

Relevant transport topics can be transformed into appropriate indicators of sustainable development (units of indicators), whose structure should support certain balance among economy, social and ecology objectives and effects. In other words, demands for sustainability using familiarity with perspective, assumptions and limitations of each indicator [3].

In order to make such objectives accomplished, it is important to include following in indicators of sustainability of transport [17]:

Planning process-based on quality analyses during decision making process.

Options and incentives-for users of services, through adequate transport offer and incentives for selection of the most efficient transport route.

Behaviour during transport-kinds of vehicles, participation of certain kinds of transport.

Physical effects-emission of different pollutions, consequences of traffic accidents, use of land.

Effect of people on the environment-diseases and death, degradation of environment.

Economic effects-estimation of costs, observing productivity, efficiency of transport systems.

Performances-following the performance or level of realization of planned objectives.

Professional literature provides a large scale of different approaches to methodology. These approaches are used for creation of indicators for estimation of transport sustainability [12], while contribution of Todd Litman and Victoria Transport Policy Institute can be considered by the scope of the research and complexity of the approach.

Presentation of four kinds of indicators implied that organization which really wants to achieve dramatic improvements in performances should select and get aligned exclusively with indicators of key performances, in this case-services, in order to use them for obtaining indicators of key results, indicators of achieved success of transport organization.

Within traffic/transport theory and practice, KPIs are differently treated. The differences could appear according to the following factors: aspect of interest with significance of the observing and its objectives, development policy, objectives and strategies in country and region, development of scope of technologies, objects of measuring and following (system, process, user), target use of KPIs on decision making levels (strategic, tactical, operative), according to [10].

Quality of functioning of transport organization, its processes and subprocesses is mostly focused on the following primary areas:

- Traffic exploitation (vehicles, infrastructure, users...),
- Safety and technical exploitation (level of vulnerability, maintaining of all resources...),

- Environmental protection (noise, air, water...),

- Business economy (costs, prices, income, investments, credits, loans...),

- Social development (employment, regional development...).

Each of these areas provides its models of KPIs which are not universal since they include numerous different KPIs. Therefore, models are adapted to specific needs of each organization whose quality is estimated. Development of individual system of KPIs aligned with certain organization starts from development, selection and defining of real measures of indicators of each individual objective as improvement performance which adequately characterizes level of objectives realization.

It is important to use those KPIs which include provided data and information sources and which represent good basis for comparison of obtained and provided service [10].

Analyses on different approaches for defining performance indicators can be highlighted by OECD approach, approach by organization which formed experts group in 1995 with the plan to provide suggestion of performance indicators through its researches related to road transport

During the time, authors and researchers started to share KPI in groups/categories so there are different approaches and divisions related to such issues.

Literature often quoted division of key performances in five groups/categories: mobility-reliability, safety, quality of environment, transport costs and development and employment [13].

Quality of transport service of passenger transport is standardized by the European standard CEN 13816 due to its importance. It includes eight groups of KPIs, which generally describe service of passengers transport, quality of transport service and effect of transport on the environment.

According to the scope of research and complexity of approach related to the issues of KPI in transport sector, the contribution of Todd Litman and Victoria Transport Policy Institute is considered as highly important. In his works related to planning of transport, Litman indicated the need to replace the old paradigm related to performance indicators (traffic speed, road quality, gasses emission, accidents on roads) with a new one which explains multimodal approach to transport service including complex approach to modeling, simultaneous calculation of time, costs, conformity, safety and environmental protection, which is the precondition of realization of transport services [2].

The analysis of different approaches to defining performance indicators in science and professional literature served as a basis for defining the unit of key performances and indicators, which are adapted to practice and legislative business frames of transport organizations in Serbia.

Tab. 1 presents favorable trend of key performances and indicators, including all parties interested in realization of planned objectives and business improvement. 
Table 1 Key performances and their indicators for transport organization in relation to sustainability requirements

\begin{tabular}{|c|c|c|c|c|c|}
\hline No & Key performance & The goal & Indicator & Desired trend & Stakeholders \\
\hline 1 & 2 & 3 & 4 & 5 & 6 \\
\hline \multicolumn{6}{|c|}{ 1. Economic sustainability of the transport organization } \\
\hline \multirow{9}{*}{1.1} & \multirow{9}{*}{$\begin{array}{l}\text { Economic } \\
\text { efficiency of the } \\
\text { organization }\end{array}$} & \multirow{9}{*}{ Increase of economic efficiency } & Business income & & \multirow{9}{*}{$\begin{array}{l}\text { Owner, Employee, } \\
\text { State }\end{array}$} \\
\hline & & & Business expenses & & \\
\hline & & & Subsidies & & \\
\hline & & & Liquidity & & \\
\hline & & & Debt & & \\
\hline & & & Activity & & \\
\hline & & & Profitability & & \\
\hline & & & Economics & & \\
\hline & & & Productivity & & \\
\hline \multirow{6}{*}{1.2} & \multirow{6}{*}{$\begin{array}{l}\text { Production } \\
\text { efficiency of } \\
\text { resources }\end{array}$} & \multirow{6}{*}{ Increase in production efficiency } & Production efficiency of the vehicle & & \multirow{6}{*}{ Owner, Employee } \\
\hline & & & Production efficiency of employees & & \\
\hline & & & Cost Efficiency & & \\
\hline & & & Economic efficiency & & \\
\hline & & & Energetic efficiency & & \\
\hline & & & Resource Usage Measures & & \\
\hline \multirow{2}{*}{1.3} & \multirow{2}{*}{$\begin{array}{l}\text { Energetic } \\
\text { efficiency }\end{array}$} & \multirow{2}{*}{$\begin{array}{l}\text { Reducing consumption and costs of } \\
\text { petroleum }\end{array}$} & Consumption of petroleum products & & \multirow{2}{*}{$\begin{array}{l}\text { Owner, Employee, } \\
\text { Society }\end{array}$} \\
\hline & & & Costs of petroleum products & & \\
\hline \multirow{9}{*}{1.4} & & & Number of vehicles in traffic & & \\
\hline & & & Number of passengers carried & & \\
\hline & & & Number of passenger kilometers & & \\
\hline & & & Average transport route & & \\
\hline & & & Gross revenue from transport & & \\
\hline & & availability & Arrivals per $1 \mathrm{~km}$ & & Owner, Employee \\
\hline & & & Coefficient of technical safety of the vehicle fleet & & \\
\hline & & & Coefficient of utilization of the vehicle fleet & & \\
\hline & & & $\begin{array}{l}\text { Percentage of realization of basic elements of a } \\
\text { driving order }\end{array}$ & & \\
\hline & & & Organizational support services & & \\
\hline & & & Benefit of service for use & & Owner, Employee, \\
\hline & & Improving the quality of the transport & Stability of service & & Service users \\
\hline & & & Service evaluation & & \\
\hline & & Informatics & Invested funds in informatics & & Owner, Employee \\
\hline 1.5 & $\begin{array}{l}\text { Productivity of the } \\
\text { resource }\end{array}$ & Human Resources Development & $\begin{array}{l}\text { Funds invested in education and education of } \\
\text { employees }\end{array}$ & & Employee \\
\hline & & Safety and protection at work & Invested in safety and security at work & & Service users \\
\hline & & Optimizing the number of employees & Number of employees & & Owner, Employee \\
\hline & & Improving the reward system & Average earnings in the organization & & Owner, Employee \\
\hline & & Maintenance & Invested funds in maintenance of fixed assets & & State, society \\
\hline & & Investments & Invested funds in investment activities & & Service users \\
\hline & & Social susta & nability of the transport organization & & \\
\hline 2.1 & Equality/justice & Adapt the transport system to all users & $\begin{array}{l}\text { Variety of transport systems (elevators, } \\
\text { escalators, ramps..) }\end{array}$ & & $\begin{array}{l}\text { Society Service } \\
\text { users }\end{array}$ \\
\hline & & & $\begin{array}{l}\text { Accessibility of destinations and infrastructure to } \\
\text { persons with disabilities and other restrictions }\end{array}$ & & \\
\hline 2.2 & $\begin{array}{l}\text { Safety, security, } \\
\text { health }\end{array}$ & $\begin{array}{l}\text { Reducing the risks that lead to traffic } \\
\text { accidents }\end{array}$ & Number of victims of traffic accidents & & $\begin{array}{l}\text { Owner, Employee, } \\
\text { State, Society, } \\
\text { Service users }\end{array}$ \\
\hline & & & $\begin{array}{l}\text { Number of accidents and accidents caused by the } \\
\text { fault of employees }\end{array}$ & & \\
\hline 2.3 & $\begin{array}{l}\text { Social } \\
\text { Development }\end{array}$ & $\begin{array}{l}\text { Assistance in creating an inclusive and } \\
\text { attractive community and supporting } \\
\text { cohesion }\end{array}$ & Quality road and street environment & & Society \\
\hline & & & Pacing for pedestrians and cyclists & & \\
\hline & & & Adequate land use & & \\
\hline 2.4 & $\begin{array}{l}\text { Preservation of } \\
\text { cultural heritage }\end{array}$ & Respect and protection of cultural heritage & Preservation of cultural resources and traditions & & Society \\
\hline & & 3. $\quad$ Sustainability of $\mathrm{tl}$ & e environment of the transport organization & & \\
\hline 3.1 & $\begin{array}{l}\text { Prevention of air } \\
\text { pollution }\end{array}$ & Reduction of emissions of harmful gases & Emission of harmful gases & & Society \\
\hline 3.2 & $\begin{array}{l}\text { Prevention of } \\
\text { noise }\end{array}$ & Minimizing traffic noise & Traffic noise level & & \begin{tabular}{|l|} 
Owner, Employee, \\
Service users \\
\end{tabular} \\
\hline 3.3 & $\begin{array}{l}\text { Water quality } \\
\text { protection }\end{array}$ & Reduction of waste pollution & Level of waste & & Society \\
\hline 3.4 & $\begin{array}{l}\text { Protection of } \\
\text { biodiversity }\end{array}$ & Preserving the quality of the habitat & Support for "smart" development & & Society \\
\hline & & 4. Sustainability of perfor & nance management of the transport organizations & & \\
\hline 4.1 & Output results & Defining Output Results & Financial and non-financial & & Owner, Employee \\
\hline 4.2 & System approach & Application of the system approach & Financial and non-financial & & Owner, Employee \\
\hline 4.3 & Additional value & Taking additional value & Financial and non-financial & & Owner, Employee \\
\hline 4.4 & $\begin{array}{l}\text { Needs and } \\
\text { opportunities }\end{array}$ & Analysis of needs and possibilities & Financial and non-financial & & Owner, Employee \\
\hline 4.5 & Causes & Analyzing the causes & Financial and non-financial & & Owner, Employee \\
\hline 4.6 & Designing & Improving design & Financial and non-financial & & Owner, Employee \\
\hline 4.7 & Development & Improving development & Financial and non-financial & & Owner, Employee \\
\hline 4.8 & Solutions & Improving the solution & Financial and non-financial & & Owner, Employee \\
\hline 4.9 & Evaluation & Measurement of results & Financial and non-financial & & Owner, Employee \\
\hline
\end{tabular}


Therefore, the unit of key performances and appropriate indicators of key performances, divided in four categories of business sustainability, is defined. These categories are: economic and social sustainability, sustainability of the environment and sustainability of management of performances of transport organization. They are developed as a result of the realization of all elements of a transport process which are used for planning and observing business realization of a transport organization.

According to the way of selection and division of key indicators of performances for transport organization relating to sustainability requirements, it is possible to review and measure different dimensions of business success of a transport organization. The key contribution of approach presented in the work included defining of the fourth kind of sustainability, which is related to sustainability of performances management.

\section{RESEARCH ON CRITICAL SUCCESS FACTORS OF TRANSPORT ORGANIZATIONS IN SERBIA}

Critical Success Factors-CSFs are included in all spheres of human action, starting from sport, art, commerce to science etc. They represent a concept based on elements which are needed in order to make certain idea, project or organization achieve their mission [25].

Concept of critical success factors was firstly introduced by Ronald D. Daniel, through their publishing in Harvard Business Review (HBR) in 1979. However, wider application of this concept was provided ten years later by John F. Rockart for MIT Sloan School of Management. The CSF concept was defined in the form of several key areas within which activities must be well completed [20].

There are several categorizations of critical success factors. Two of these can be considered as the most popular.

First-it uses the area of implementation as a criterion: commerce, strategy, environment and time.

Second-it uses typical dimension and nominates nine critical success factors: finances - positive business balance, increase of incomes and obtained profit, increasing of number of buyers/users of service, increasing of satisfaction of buyers/users of service, quality, development of product/service, intellectual capital, strategic relationships, attraction and retaining of employees-in other words, overall sustainability of business [4].

Management of organization performances implies importance of identifying critical success factors in order to understand business results in a right way, especially in organizations which implemented SMS/IMS and which include certain disbalance between achieved level of management of performances and indicators of economic sustainability of business.

\subsection{Introduction to the Research}

Considering the fact that the number of critical factors of success which are mentioned in the literature varies from 5 to 8 , and even to 24 factors [4], the research in this work was based on ranging by the importance of 5 factors, which are formulated as a research question for experts of the companies in which researches were conducted (Tab. 2).

Table 2 Research question

\begin{tabular}{|l|l|l|}
\hline 1 & CRITICAL FACTORS OF SUCCESS OF ORGANIZATION: \\
\hline 1.1 & The environment in which the organization operates & \multirow{3}{*}{} \\
\hline 1.2 & Depolitization of management & \\
\hline 1.3 & Professional and trained staff & \\
\hline 1.4 & Teamwork and interpersonal relations & \\
\hline 1.5 & Rewarding &
\end{tabular}

Nowadays, business of transport organizations worldwide is stressed with certain level of conflict of interests. While pursuing the profit, organizations exhaust their resources, spend knowledge and health of their employees, large amounts of energy which significantly pollute environment, all with intention to promote and achieve the best possible business results.

Main business challenges of transport organizations in the world do not any longer include liquidity, profit increase, lack of capital, motivation of workers, client's complaints, competition or any other problem they were faced with during last decades, because they managed to implement modern management concepts during that period. These concepts are aligned with demands of transport market. On a long-term plan, even large and successful organizations are faced with the problem of sustainability of business, especially in conditions when there is awareness that organization interests are no longer considered as a priority over interest of social community and environmental protection [6].

Unlike transport organizations which are more-less successful at the European (World) market of transport services, organizations from our country have issues with the following: liquidity, old train vehicles, not motivated employees, unsatisfied customers. Due to all mentioned, the greatest challenge of business is actually sustainability of business.

According to defined criteria, research is approached by analysis of four transport organizations:

Organization A-Serbian Railways, Belgrade,

Organization B-Community Traffic Enterprise Belgrade, Organization C-Traffic Company Lasta, Belgrade,

Organization D-Railroad transport of Montenegro, Podgorica.

The method of expert reviewing was used for the purposes of the research. The essence of this research includes forming of conclusions according to the opinions of experts in certain areas of work, while firstly intuitive answers on defined questions were provided. However, the intuition is covered by expertise, knowledge and experience of experts, which are priceless in situations when quantitative data are not available or adequate [18].

\subsection{Selection of Participants in the Research}

Research of critical factors of success lasted continuously for three months and it included $N=132$ experts of different profiles:

Organization A-sample includes 68 respondents, who were divided into transport technology $(N=20,29,4 \%)$, strategy and development $(N=18,26,5 \%)$, traffic $(N=12$, 
$2 \%)$ business plan $(N=10,14,7 \%)$, finances $(N=8$, $11,8 \%$ ).

Organization B-sample includes 25 respondents, who were divided into strategy and development $(N=11$, $44,0 \%)$, traffic $(N=6,24,0 \%)$, business plan $(N=5$, $20,0 \%)$, finances $(N=3,12,0 \%)$.

Organization $\mathbf{C}$-sample includes 21 respondents, who were divided into strategy and development $(N=10$, $47,7 \%)$, business plan $(N=5,23,8 \%)$, finances $(N=4$, $19,0 \%)$, traffic $(N=2,9,5 \%)$.

Organization D-sample included 18 respondents, who were divided to traffic $(N=5,27,8 \%)$, business plan $(N=$ 4, 22,2\%), finances $(N=4,22,2 \%)$, strategy and development $(N=3,16,7 \%)$ and business plan $(N=2$, $11,1 \%)$.

\subsection{Research Results} short.

Fig. 2 presents research results at each organization in

In Organization A, $40 \%$ of respondents considered that professional and trained people are a critical factor of success, which is followed by depolitization of management including opinions of $25 \%$ of respondents, then team work and human relationships and ambience in which organization works. The last place is dedicated to rewarding.

Obtained results can be explained in several ways. Professional and trained people can be a dominant factor of sustainability of organization business but it also can be concluded that domination of this factor originated from the fact that during last decades, management staff and management of organizations were selected by the Government, mostly according to political line.

In Organization B, $36 \%$ of respondents considered that ambience in which organization works is a critical factor of success, which is followed by depolitization of management including the opinion of $24 \%$ of respondents, professional and trained staff and team work and human relationships with the opinion of $16 \%$ of respondents and rewarding by the opinion of $8 \%$ of respondents.

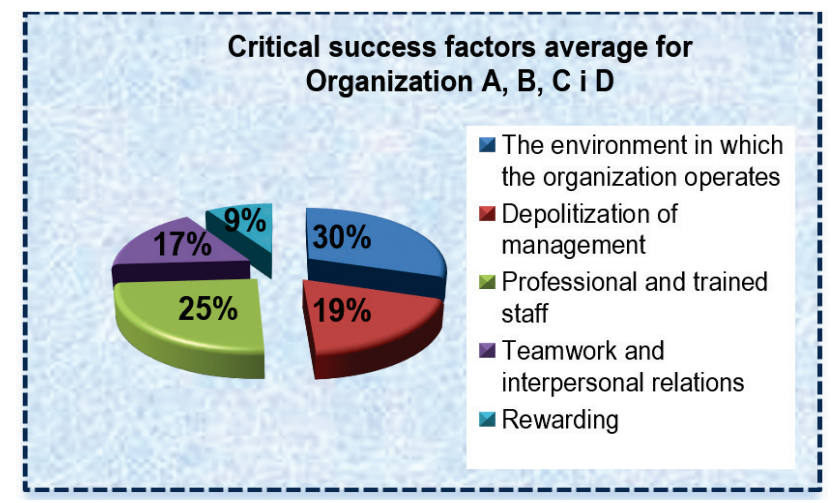

Figure 2 The average dominance of critical success factors of First Rang

Most respondents from the Organization $\mathrm{C}$ considered that ambience of business was a critical factor of success $38 \%$ of respondents, followed by $19 \%$ of respondents who considered professional and trained staff as a key factor, while the opinion of $14 \%$ of respondents was related to depolitization of management, teamwork and rewarding.
Regarding Organization D, the key factors of success include ambience according to the opinion of $33 \%$ of respondents, professional and trained staff by the opinion of $28 \%$ of respondents and teamwork and human relationships by the opinion of $22 \%$ of respondents.

The final recapitulation of research related to the estimation of average domination of factors of success, given Range 1 by experts is presented in Fig. 2 for observed transport organizations. It is clear that $30 \%$ of respondents consider Ambience in which organization works as a dominant factor which affects the business of transport organizations. It is followed by Professional and trained staff by the opinion of $25 \%$ of respondents. Depolitization of management is at the third place with opinion of $19 \%$ of respondents and it is followed by Teamwork and human relationships by the opinion of $17 \%$ of respondents. The Rewarding is included by the opinion of $9 \%$ of respondents.

Research showed that the ambience of transport organization and the professional and trained staff are critical factors of success of a transport organization, which is followed by the depolitization of management, teamwork and human relationships, and rewarding at the last place.

Obtained results can be considered as appreciated and motivating in a certain way because they showed that the road to the promotion of business of each organization must be led through the teamwork of employees and good human relationships.

The fact that the critical factor of success related to rewarding is at the last place in this research can be surprising. It does not mean that employees are satisfied with the rewards they receive for their work because the average salaries in our country are a way below average salaries in the EU countries.

In a certain way this can be explained by the situation in our society. Our society is related to a high level of unemployment. Employed people obviously want to keep their jobs at any cost which opens the issue of their motivation for that job and its effect on sustainability of organization business.

Research of key factors of success implies a fact that all interested parties are participants in the process of making a successful transport organization while special ones go to the state which has the power to use appropriate legislative frameworks to create/change business ambience in which organizations have to do business with positive balance while not taking into account the interests of users of transport services.

Beside the state, the role of management (leaders) is also important. It is expected from them to use their proactive behavior and apply modern knowledge and achievements to improve business of transport organizations, focusing on satisfying the needs of users of services.

\section{CONCLUSION}

Within modern conditions, competitive success of a transport organization depends on its ability to engage and efficiently use its material and nonmaterial resources, to quickly adapt to changeable conditions in the environment 
and to be the first to recognize and satisfy changeable needs and demands of consumers.

Using traditional systems for measurement of performances and control, based on financial - calculating system is no more sufficient for satisfying mentioned needs of transport organizations.

As a result of the need of organization to use more adequate systems for measuring performances which would much better respond to modern conditions of business and demands for successful management of organization, a group of systems which can be considered as modern systems for measurement of performances of organizations was developed.

Modern systems for measurement of performances of an organization are deemed to respond to modern needs of management of organization as a whole and to provide more perfect economic resources for supporting decision making processes. Very often, modern systems for measurement of performances demand adaptation of the entire management system in order to obtain optimal results and promote business success of organization.

Identifying the indicators of sustainability is actually used for recognizing the criteria placed by sustainable development through which the existing, more traditional way of management of technological development is limited. This development is oriented to satisfying different consumer needs since industrial revolution.

The key contribution can be dedicated to development of universal unit of key performances and following indicators of key performances, which include economic and social sustainability and sustainability of the environment, sustainability of management of performances of transport organization.

Beside the mentioned, the importance is also indicated in the research conducted in order to determine critical success factors of a transport organization. The purpose of this determination was to use obtained information and take different measures for providing the principles and the business system which can promote and contribute to long term sustainability of business of transport organizations in Serbia.

\section{REFERENCES}

[1] Arsić, Lj., Cvetković, K., \& Adžić, M. (2011). Primena metodologije 20 ključeva u funkciji unapređenja kvaliteta poslovanja preduzeća. $1^{\text {st }}$ International Scientific Conference oneconomic development and standard of living "EDASOL2011 - EconomicDevelopment and Standard of Living", Banja Luka

[2] Aquinis, H. (2007). Performance management. Pearson Prentice Hall; Upper Saddle River, New Jersey

[3] Bojković, N., Macura, D., Pejčić-Tarle, S., \& Bojović, N. (2011). A comparative assessment of transport sustainability in central and eastern European countries with a brief reference to the Republic if Serbia. Internationa Journal of Sustainable Transportation, 5(6), 319-344. https://doi.org/10.1080/15568318.2010.539664

[4] Black, S. \& Porter, L. (1996). Identification of critical factors of TQM. Decision Sciences, 27(1), 1-21. https://doi.org/10.1111/j.1540-5915.1996.tb00841.x

[5] Cal Trans (2008). Transportation System Performance Measures (TSPM), California Department of Transportation https:www.dot.ca.gov/hq/tsip/index.php
[6] Colbert, B. A. \& Kurucz, E. C. (2007). Three conceptions of triple bottom line business sustainability and the role for HRM. Hum. Resour. Plan, 30, 21-29

[7] CTE (2008). Improved Methods For Assessing Social, Cultural, and Economic Effects Of Transportation Projects, NCHRP Project 08-36

[8] CST (2003). Sustainable Transportation Performance Indicators, Centre for Sustainable Transportation http://cst.uwinnipeg.ca/completed.html

[9] Daum, H. J. (2002). Performance Management and Business Controlling in the $21^{\text {st }}$ Century, SAP AG, A02 (Daum). https:www.juergendaum.com/mybook.htm

[10] Davidović, B. (2008). Menadžment kvaliteta u transport. Intelekt. Visoka tehička škola, Kragujevac

[11] Filipović, S. (2005). Osnovi tehnologije transporta-Osnovni pojmovi teorije transporta $i$ tehnologije drumskog transporta. pisana predavanja, Saobraćajni fakultet, Univerzitet u Beogradu

[12] Gudmundsson, H. (2003). Making concept matter: sustainable mobility and indicator systems in transport policy. International Social Science Journal, 55(2). https://doi.org/10.1111/j.1468-2451.2003.05502003.x

[13] Jin, M., Wang, H., \& Walden, C. T. (2004). System Performance Measures for Intermodal Transportation with a Case Study and Industrial Application. University of Denver and Mississippi State University, Available from: http://ncit.msstate.edu

[14] Jović, J. (2011). Indikatori u održivom planiranju saobraćaja. Saobraćajni fakultet, Beograd, Rezultat rada na projektu Ministarstva za nauku i tehnološki razvoj Republike Srbije br. 15021

[15] Kozuharov, S. (2011). Mezzo economics analytical approach as the propulsive part of managerial economics in tourism. UTMS Journal of Economics , 2(2), 213-219.

[16] Krstić, B. \& Sekulić, V. (2013). Upravljanje performansama preduzeća. Ekonomski fakultet, Niš

[17] Litman, T. (2013). Planning Principles and Practices. Victoria Transport Policy Institute, http://www.vtpi.org/planning.pdf

[18] Mair, C., Martincova, M., \& Shepperd, M. (2009). A Literature Review of Expert Problem Solving using Analogy. EASE 2009 Evaluation and Assessment in Software Engineering. https://doi.org/10.14236/ewic/EASE2009.13

[19] Pejčić-Tarle, S. \& Bojković, N. (2012). Evropska politika održivog razvoja. Saobraćajni fakultet, Beograd

[20] Rockart, J. F. (1979). Chief executives define their own data needs. Harvard Business Review, 57(2), 81-93.

[21] STI (2008). Sustainable Transportation Indicators: A Recommended Program to Define a Standard Set of Indicators For Sustainable Transportation Planning, Sustainable Transportation Indicators Subcommittee, VTPI, http://www.vtpi.org/sustain/sti.pdf

[22] Tomović, N., Pejčić-Tarle, S. \& Gladović, P., (2012) Sistem upravljanja kvalitetom $\mathrm{u}$ funkciji unapređenja performansi transportnih organizacija. International Conventionon Quality - ICQ 2012, Belgrade, 05 $5^{\text {th }}$ June - 07 $7^{\text {th }}$ June 2012., Belgrade, Serbia

[23] TCRP - Transit Cooperative Research Program, Annual Report of Progress. (2010). Transportation research board, Washington, D.C.

[24] TRB (2008), Performance Measurement Practice Performance Measurement Committee (ABC30). Transportation Research Board

[25] Veen-Dirks, P. \& Wijn, M. (2002). Strategic Control: Measuring Critical Success Factors with Balanced Scorecard. Long Range Planning, 35(4), 407-427. 


\section{Contact information:}

Nena TOMOVIĆ, PhD, Assistant professor

University Business Academy,

Cvećarska 2, 21000 Novi Sad, Serbia

E-mail: nena.tomovic@fimek.edu.rs

Milos ARSIĆ, PhD, Full professor

High shipping school of academic studies,

Bulevar vojvode Mišića 37, 11000 Belgrade, Serbia

E-mail: misaarsa@yahoo.com

Radoljub TOMIĆ, PhD, Associate professor

Fakultet za informacione tehnologije i inženjerstvo,

Jurija Gagarina 149a, 11000 Belgrade, Serbia

E-mail: radoljub.tomic@fiti.edu.rs

Ištvan BODOLO, PhD, Assistant professor

University Business Academy,

Cvećarska 2, 21000 Novi Sad, Serbia

E-mail: istvan.bodolo@fimek.edu.rs

Desanka VLAČIĆ, MSc

Faculty of Traffic and Communications and Logistics-Budva,

Žrtava fašizma bb, 85310 Budva, Montenegro

E-mail:vdesa@t-com.me 